\title{
Kesiapan Menghadapi Menarche pada Remaja Putri Prapubertas Ditinjau dari Kelekatan Aman Anak dan Ibu
}

\author{
Nurul Hidayah, Sara Palila \\ UIN Sunan Kalijaga, Jl. Laksda Adisucipto Yogyakarta \\ e-mail: nurulhanafiah11@gmail.com
}

\begin{abstract}
This study aims to determine the relationship between mother's secure attachment to the readiness of prepubertal girl to face first menstruation (menarche). The participants were 74 elementary students at V and VI grade in Budi Mulia Elementary School, Seturan. This study used quantitative research method. Measuring instruments were menarche preparedness scale and secure attachment scale. Hypothesis testing was conducted using a statistical technique test of Pearson Product Moment Correlation with SPSS software. The results showed a correlation coefficient $(r x y)=.305$ with significance level of $p=.008$ ( $p<.01)$, so the hypothesis was accepted. This result indicates that there is a significant positive correlation between mother's secure attachment to the pre-pubertal girls' readiness to face first menstruation (menarche).
\end{abstract}

Keywords: secure attachment, menarche readiness, adolescents

\begin{abstract}
Abstrak
Penelitian ini bertujuan untuk mengetahui hubungan antara kesiapan menghadapi menstruasi pertama (menarche) dengan kelekatan aman anak dan ibu dengan pada remaja putri prapubertas. Sampel dalam penelitian ini adalah 74 siswi kelas V dan VI di SD Budi Mulia Dua Seturan. Penelitian ini menggunakan metode penelitian kuantitatif. Alat ukur yang digunakan dalam penelitian ini adalah skala kesiapan menghadapi menarche dan skala kelekatan aman anak dan ibu. Uji hipotesis dilakukan dengan menggunakan teknik statistik yaitu uji korelasi product moment dari Pearson dengan menggunakan program komputer SPSS. Hasil uji korelasi menunjukan koefisien korelasi $(\mathrm{rxy})=.305$ dengan taraf signifikansi $\mathrm{p}=.008$ ( $\mathrm{p}<.01)$, sehingga hipotesis yang diajukan diterima. Temuan tersebut menunjukkan bahwa terdapat hubungan positif yang signifikan antara kelekatan aman ibu dan anak dengan kesiapan menghadapi menstruasi pertama (menarche).
\end{abstract}

Kata Kunci: kelekatan aman, kesiapan menghadapi menarche, remaja

\section{Pendahuluan}

Salah satu tahap perkembangan manusia yang cukup penting adalah masa remaja. Pubertas akan terjadi pada masa ini yang ditandai dengan perkembangan yang sangat mencolok pada aspek fisik, seksual, dan psikososial. Masa remaja ditandai dengan kemunculan tanda-tanda pubertas yang berlanjut hingga mencapai kematangan seksual. Pubertas adalah perubahan kematangan fisik secara cepat yang meliputi perubahan tubuh dan hormonal, yang biasanya muncul di awal masa remaja (Santrock, 2002). Perubahan-perubahan fisik pada masa ini mencakup penampilan fisik seperti bentuk tubuh, proporsi tubuh, dan fungsi fisiologis (kematangan organorgan seksual).

Pada perempuan, pubertas berbentuk peristiwa haid pertama yang disebut menarche. Menurut Sarwono (2010), menarche adalah tahap perkembangan fisik ketika alat reproduksi manusia mencapai kematangannya. Usia menarche bervariasi pada setiap perempuan. Pada umumnya menarche terjadi pada usia 12-14 tahun, namun saat ini terdapat kecenderungan penurunan usia menarche ke usia yang lebih muda sehingga banyak siswi Sekolah Dasar (SD) yang mengalami menarche. Hal 
ini bergantung pada beberapa faktor, seperti kesehatan, berat badan, dan status nutrisi.

Fase tibanya haid ini merupakan satu periode di mana gadis benar-benar telah siap secara biologis menjalani fungsi kewanitaannya. Maka bagi perempuan, peristiwa haid menduduki satu eksistensi psikologis yang unik, yang bisa mempengaruhi sekali persepsi anak gadis terhadap realitas hidup, baik pada masa remaja maupun setelah dia menjadi dewasa. Gejala psikologis dari menarche diantaranya kecemasan dan ketakutan yang kuat oleh keinginan untuk menolak proses fisiologis tersebut (Kartono, 2006). Remaja putri yang mengalami menarche sering merasakan kebingungan dan kesedihan (Dianawati, 2006). Hal ini terjadi dikarenakan kebanyakan remaja tidak memahami dasar dari perubahan yang terjadi pada dirinya.

Ketika menjelang menstruasi, setiap remaja perempuan memiliki sikap dan respon yang berbeda. Selaras dengan Astiti dan Pudjono (2004) yang mengemukakan bahwa persepsi terhadap menstruasi dapat berupa: persepsi positif, ketika diasosiasikan dengan kedewasaan; dan persepsi negatif, ketika diasosiasikan dengan kondisi yang membatasi, mitos menstruasi dan ketidaknyamanan.

Menurut Conger (Sriwindari, 2002), dari 475 remaja putri, kebanyakan merasa biasa saja, cemas, atau takut, dan hanya $10 \%$ dari mereka yang merasakan antusias, penasaran dan bangga ketika mengalami menarche. Sedangkan penelitian yang dilakukan oleh Bharatwaj, Vijaya, dan Sindu (2014) menyatakan bahwa dari 101 responden remaja putri, hanya $33.6 \%$ yang memiliki pengetahuan tentang menstruasi dan merasa nyaman saat menghadapi menarche, sedangkan $61.3 \%$ responden tidak memiliki pengetahuan tentang menstruasi. Sekitar $49.5 \%$ responden dalam penelitian tersebut merasa panik dan $50.49 \%$ merasa buruk, terbatasi dan depresi. Emosi negatif ini muncul pada anak perempuan yang tidak dipersiapkan pada permulaan menstruasi (Yeung, 2005). Hasil penelitian ini menunjukkan hampir sebagian remaja putri memberikan respon negatif terhadap menarche, seperti perasaan malu, cemas, takut dan bingung.

Kesiapan menghadapi menarche dapat dilakukan dengan cara memberikan informasi dan perhatian pada remaja putri pada masa menghadapi menarche, dengan demikian remaja putri akan menjadi lebih tenang dan siap menyambut datangnya menarche. Sumber informasi utama sebenarnya berasal dari ibu dan kakak perempuan (Tiwari, 2006). Orang tua terutama ibu harus memberikan penjelasan tentang menarche pada anak perempuannya, agar anak lebih mengerti dan siap dalam menghadapi menarche (Muriyana, 2008).

Kelekatan aman yang terbentuk antara anak dan ibu dapat membantu remaja putri lebih mudah memahami menarche. Peran keluarga, khususnya ibu sangat penting dalam mengenalkan menarche pada remaja putri agar mereka siap menghadapi menarche. Ibu sebagai wanita yang pernah mengalami menarche dapat dijadikan sebagai tempat untuk bertanya tentang masalah tersebut.

Namun, pada kenyataannya, tidak semua ibu dapat memberikan informasi yang memadai kepada putrinya. Sebagian ibu enggan membicarakan tentang menarche secara terbuka. Selain dikarenakan terbatasnya atau kurang mampunya pengetahuan ibu menyampaikan informasi tersebut kepada anak juga dikarenakan banyak ibu masih merasa canggung dan menganggap bahwa anak perempuan dapat mempersiapkan menstruasi sendiri.

Riset awal yang dilakukan peneliti dengan metode wawancara melibatkan empat siswi di SD Budi Mulia Dua. Empat orang tersebut terdiri dari satu orang siswi yang sudah mengalami dan tiga siswi yang belum mengalami menarche. Siswi yang sudah mengalami menarche mengemukakan bahwa ia mengalami rasa panik dan malu ketika menghadapi menarche yang 
saat itu terjadi di sekolah, ditambah dengan reaksi yang kurang menyenangkan dari teman-teman sekolahnya. Sedangkan tiga siswi yang belum mengalami menarche mengemukakan bahwa mereka merasa khawatir dan bingung jika nanti mengalami menarche pada saatnya. Beberapa hal tersebut menunjukkan menunjukkan bahwa kesiapan mereka dalam menghadapi menarche masih rendah.

Berdasarkan permasalahan di atas, maka penulis tertarik untuk meneliti apakah ada hubungan antara kelekatan aman terhadap ibu dengan kesiapan menghadapi menstruasi pertama (menarche). Penelitian yang dilakukan berjudul "Hubungan Antara Kelekatan Aman Terhadap Ibu dengan Kesiapan Remaja Putri Prapubertas menghadapi Menstruasi Pertama (Menarche)."

\section{Remaja Putri Prapubertas}

Remaja adalah tahap dimana seseorang mengalami perkembangan tanda-tanda seksual sekundernya hingga mencapai kematangan seksual (Sarwono, 2010). Hurlock (2004) menjelaskan masa puber merupakan masa yang tumpang tindih, karena meliputi tahun-tahun akhir masa kanak-kanak dan tahun-tahun awal masa remaja. Ada perbedaan antara pria dan wanita pada tiga tahap pembagian masa puber. Pada wanita, tahap pra puber di usia 10-13 tahun, puber 13-17 tahun, dan pasca puber 17-21 tahun. Pada pria, tahap pra puber 14-16 tahun, puber 14-17 tahun, dan pasca puber 17-21 tahun).

Dari uraian di atas, dapat disimpulkan prapubertas adalah masa peralihan dari masa kanak-kanak ke masa remaja, dengan rentang usia antara 10 sampai 13 tahun dan secara khusus pada usia ini ditandai dengan perubahan fisik, kognitif dan sosial.

\section{Kesiapan Menghadapi Menarche}

Datangnya menstruasi pertama, merupakan salah satu peristiwa terpenting pada masa pubertas remaja putri sekaligus pertanda biologis dari kematangan seksual.
Menurut Yusuf, Rina, dan Septi (2014), menarche adalah haid yang pertama kali terjadi pada wanita, dan merupakan ciri khas dari kedewasaan seorang wanita yang sehat dan tidak hamil.

Berdasarkan pengertian di atas, dapat disimpulkan bahwa menstruasi pertama atau menarche adalah menstuasi awal yang biasa terjadi pada masa pubertas dalam rentang usia sepuluh tahun sampai enam belas tahun yang menjadi pertanda biologis dari kematang seksual wanita.

Saat menghadapi menarche, dibutuhkan kesiapan mental yang baik. Kesiapan menghadapi menstruasi pertama (menarche) adalah keadaan yang menunjukkan bahwa seseorang siap untuk mencapai salah satu kematangan fisik yaitu datangnya menstruasi pertama (menarche), yang keluar dari tempat khusus wanita pada saat menginjak usia sepuluh sampai enam belas tahun, yang terjadi secara periodik (pada waktu tertentu) dan siklik (berulang-ulang) (Fajri \& Khairani, 2011).

Menurut Yusuf (2002) ada tiga aspek mengenai kesiapan. Aspek yang pertama adalah pemahaman, yakni pengalaman seseorang terhadap kejadian yang dialaminya. Ketika seseorang mengerti dan mengetahui akan kejadian yang dialaminya, hal ini dapat membantu dirinya untuk merasa siap dalam menghadapi hal-hal yang terjadi.

Aspek kedua adalah penghayatan. Aspek ini merupakan kondisi di mana seseorang merasa siap bahwa segala hal yang terjadi secara alami akan terjadi pada hampir semua orang. Hal ini juga merupakan sesuatu yang wajar, normal dan tidak perlu dikhawatirkan. Selain itu, individu juga merasakan keyakinan yang tinggi, khususnya terkait pandangan agama (Islam). Tuhan Yang Maha Esa telah memberikan karunia kepada perempuan berupa pengalaman menstruasi. Yusuf dkk. (2014) mengatakan bahwa seorang perempuan dikatakan baligh ketika tiba menstruasi, yang berarti sudah memiliki kewajiban terhadap syari'at agama. Sese- 
orang yang berempati berarti dapat melakukan transferensi perasaan positif terhadap seseorang yang mengalami kejadian yang serupa dengannya.

Aspek ketiga yaitu kesediaan, merupakan tindakan secara langsung terhadap kesempatan yang hadir, sehingga menjadi bagian pengalaman hidup. Perbandingan antara remaja perempuan yang bersiap dengan yang tidak dalam menghadapi menstruasi pertama ditunjukan oleh sikap positif (siap) dan negatif (tidak siap). Remaja perempuan yang bersikap negatif cenderung merasakan kerepotan, kekotoran, ketidaknyamanan sehingga aktivitas terbatas dan emosi fluktuatif. Banyak alasan yang melatarbelakangi tidak siapnya remaja perempuan dalam menghadapi menstruasi pertama. Seperti, orang tua minim pendidikan seks pada anak. Pendidikan seks merupakan kewajiban orangtua modern, meskipun hal ini mestinya dilakukan sejak dulu. Dengan begitu, anak perempuan tidak akan merasa cemas dan lebih positif dalam menyikapi datangnya menstruasi pertama yang berdampak pada perubahan fisik dan psikologis.

Dari penjelasan di atas, dapat disimpulkan bahwa kesiapan menghadapi menarche adalah keadaan yang menunjuk-kan bahwa seseorang siap untuk mencapai salah satu kematangan fisik yaitu datangnya menstruasi pertama (menarche) sebagai proses yang normal. Aspek-aspek menstruasi pertama (menarche) antara lain: aspek pemahaman, aspek penghayatan dan aspek kesediaan.

\section{Kelekatan Aman}

Menurut McCartney dan Dearing (2002), kelekatan merupakan hubungan secara emosional yang dibangun oleh anak biasanya terhadap orangtua dan memiliki arti penting. Bowlby (dalam Baron \& Byrne, 2003) mengatakan usia kelekatan memiliki ketahanan yang lama dan bermula saat interaksi pertama anak dengan seorang ibu. Bowlby dan Ainsworth (dalam
Santrock, 2003) menambahkan, gaya kelekatan terbagi kedalam dua jenis kelekatan aman dan, kelekatan tidak aman, juga terbagi menjadi kelekatan menghindar dan cemas.

Helmi (1999) berpendapat individu yang memiliki kelekatan aman memiliki ciri-ciri sebagai berikut: pertama, model mental diri; orang berharga, penuh dengan dorongan. Kedua, model mental orang lain; orang yang bersahabat, dapat dipercaya, responsif dan penuh kasih sayang. Menurut Santrock (2003), kelekatan aman menjadi landasan penting bagi perkembangan psikologis pada masa kanak-kanak, remaja, dan dewasa. Biasanya ibu berperan sebagai fondasi yang aman untuk membantu mengeksplorasi lingkungannya.

Kelekatan aman ibu dan anak selama masa remaja dapat berfungsi adaptif, yang menyediakan landasan yang kokoh bagi remaja untuk dapat mewujudkan hubungan dengan teman sebaya yang lebih positif dan membuat hubungan positif dalam keluarga menjadi lebih erat. Kelekatan aman dengan orangtua terutama ibu dapat memperkecil peluang remaja untuk mengalami kecemasan dan perasaan depresi sebagai dampak peralihan dari masa anak ke dewasa (Desmita, 2005).

Berdasarkan pengertian yang telah dipaparkan sebelumnya, dapat disimpulkan bahwa kelekatan aman terhadap ibu adalah suatu hubungan emosional positif yang dibentuk ibu dan anak berperan secara konsisten bagi perkembangan psikologis dan mengikat mereka dalam suatu kedekatan yang bersifat relatif lama, dimana anak akan merasa memiliki keberartian diri yang lebih tinggi, bersahabat, dan lebih percaya diri dalam situasi sosial serta lebih asertif. Penelitian ini menggunakan aspek kelekatan aman dari Bowlby karena lebih fokus dan terperinci. Aspek-aspek kelekatan aman yang digunakan, yaitu availability (ketersediaan), angry distress, dan goal-corrected partnership. 


\section{Metode Penelitian}

Penelitian ini menggunakan pendekatan kuantitatif dengan alat pengambilan data berupa skala psikologi dengan jenis skala Likert. Dalam penelitian ini ada dua skala yang digunakan, yaitu skala kelekatan aman ibu dan anak dan skala kesiapan menghadapi menstruasi. Peneliti membuat sendiri kedua skala tersebut. Sebelum dilakukan pengambilan data, peneliti melakukan try out terlebih dahulu untuk menguji validitas dan reliabilitas skala tersebut. Batasan kriteria pemilihan aitem pada penelitian ini adalah korelasi aitem total $\geq .25$.

Skala kesiapan menarche pada awalnya terdiri dari 36 aitem, namun setelah try out terdapat 11 aitem yang tidak memenuhi batasan kriteria pemilihan aitem, sehingga hanya 25 aitem yang digunakan. Sedangkan skala kelekatan aman pada awalnya terdiri dari 42 aitem, namun setelah try out terdapat 10 aitem yang tidak memenuhi batasan kriteria pemilihan aitem, sehingga hanya 32 aitem yang digunakan.

Uji validitas isi dilakukan dengan menggunakan professional judgment dari ahli. Uji reliabilitas dilakukan setelah prosedur seleksi aitem. Koefisien reliabilitas untuk skala kesiapan menghadapi menarche sebesar .852, sedangkan koefisien reliabilitas untuk skala kelekatan anak dan ibu sebesar .893.

Setelah try out selesai dilaksanakan, maka dilakukan proses pengambilan data. Penghitungan statistika dilakukan terhadap data yang telah diperoleh untuk menemukan besaran korelasi di antara kedua variabel tersebut.

Populasi dalam penelitian ini adalah siswi kelas V dan VI di SD Budi Mulia Dua Yogyakarta. Pengambilan sampel menggunakan purposive sampling dengan kriteria berupa: (1) Remaja putri kelas V dan VI yang bersekolah di SD Budi Mulia Dua, (2) Berusia 10-13 tahun karena usia ini menurut Hurlock (2004) merupakan masa prapubertas pada remaja dan saat kriteria kematangan seksual muncul, (3) Belum mengalami menstruasi, dan (4) Masih memiliki ibu dan tinggal bersama Berdasarkan informasi angket data umum yang telah disebar sebelumnya, diperoleh subjek yang memenuhi kriteria penelitian sebanyak 74 dari 320 orang. Subjek tersebut terdiri dari 39 orang siswi kelas V dan 35 orang siswi kelas VI.

\section{Hasil Penelitian dan Pembahasan}

Peneliti melakukan uji asumsi berupa uji normalitas dan uji linearitas terhadap data hasil penelitian. Pada uji normalitas, data kesiapan menghadapi menarche memiliki nilai $\mathrm{KS}-\mathrm{Z}$ sebesar 1.265 dengan $\mathrm{p}=.081(\mathrm{p}>.005)$ yang berarti data tersebut berdistribusi normal, sedangkan data kelekatan aman anak dan ibu memiliki nilai KS-Z sebesar .950 dengan $\mathrm{p}=.328$ ( $\mathrm{p}>.05)$ yang berarti data tersebut berdistribusi normal. Uji linearitas mendapat kan hasil $\mathrm{F}$ Linearity = 7.193 dengan Sig=.011 $(\mathrm{p}<.05)$ yang berarti data tersebut linear.

Setelah data penelitian dinyatakan lolos uji asumsi, maka dilakukan uji hipotesis yaitu untuk mengetahui ada tidaknya korelasi/hubungan antara variabel kesiapan menghadapi menarche dengan kelekatan aman anak dan ibu. Uji hipotesis yang digunakan adalah formula korelasi Pearson product moment. Hipotesis korelasional ada 2 tipe yaitu berarah dan tidak berarah. Hipotesis berarah menunjukkan arah positif atau negatif sedangkan hipotesis tidak berarah hanya menjelaskan adanya hubungan (Suseno, 2012).

Berdasarkan hasil perhitungan statistik diperoleh nilai rxy (koefisien korelasi) sebesar .305 dengan $\mathrm{p}=.008(\mathrm{p}<.05)$. Hal ini menunjukkan bahwa ada hubungan positif dan signifikan antara variabel kesiapan menghadapi menarche dengan kelekatan aman anak dan ibu.

Hasil penelitian ini menyatakan bahwa kesiapan menghadapi menstruasi pertama (menarche) pada remaja putri prapubertas 
di SD Budi Mulia Dua Seturan berada pada kategori tinggi yang berjumlah 58 siswi dengan persentase $78.37 \%$. Pada kategori sangat tinggi berjumlah 11 orang dengan persentase $14.86 \%$, sedangkan pada kategori sedang berjumlah 4 siswi dengan persentase $5.40 \%$, dan pada kategori rendah berjumlah 1 orang dengan persentase $1.35 \%$.

Berdasarkan data hasil perhitungan statistik dapat diketahui bahwa mayoritas remaja putri prapubertas di SD Budi Mulia Dua Seturan memiliki kesiapan menghadapi menstruasi pertama (menarche) yang tinggi pada dirinya. Kesiapan menghadapi menarche yang tinggi pada remaja putri dikarenakan mereka mampu memaknai menstruasi pertama (menarche) sebagai hal yang positif informasi yang didapat cukup baik sehingga menimbulkan kesiapan yang menghadapi menarche pada diri mereka.

Hal tersebut didukung oleh hasil penelitian yang dilakukan Purnamasari (2010), bahwa siswi di SD Negeri 1 Candi Rejo Ungaran menunjukkan tanda kesiapan yang cukup untuk menghadapi menarche yang menurut mereka akan mereka alami secara fisik dan psikologis. Mereka juga menyatakan bahwa mereka telah mempersiapkan diri jika pada tubuh dan emosi dalam diri mereka terjadi perubahan yang signifikan setelah terjadinya menarche.

Hasil $\mathrm{R}$ square change pada analisis product moment Pearson didapat bahwa hubungan variabel kelekatan aman ibu dan anak dengan kesiapan menghadapi menarche sebesar .093. Hal ini berarti bahwa sumbangan efektif variabel kelekatan aman anak dan ibu terhadap kesiapan menghadapi menarche adalah sebesar 9.3\%. Kondisi tersebut menunjukkan bahwa tingkat konsistensi variabel kesiapan menghadapi menarche sebesar 9.3\% dapat diprediksi oleh variabel kelekatan aman, dan sisanya $90.7 \%$ ditentukan oleh faktor-faktor lain yang tidak diungkapkan dalam penelitian ini, yaitu faktor usia, sumber informasi berupa kelompok teman sebaya dan lingkungan sekolah, dan sikap.

Kelekatan aman secara positif mempengaruhi kecemasan menghadapi menarche. Semakin baik interaksi yang terjalin antara anak dengan ibu maka semakin nyaman dan berkurangnya kecemasannya sehingga memiliki kesiapan yang baik dalam menghadapi menarche. Interaksi yang terjalin dengan baik akan menimbulkan kedekatan antara anak dan ibu yang membuat remaja putri lebih terbuka dengan perubahan-perubahan yang terjadi pada dirinya. Sehingga ibu akan dengan mudah memberikan informasi terkait tentang perubahan-perubahan fisiologis yang akan di alami remaja putri tanpa merasa canggung dan tabu dalam membicarakan masalah tersebut dengan anak perempuannya.

Kesiapan seorang perempuan dalam menghadapi menarche juga dipengaruhi oleh tingkat pengetahuan anak tentang menstruasi (Nastiti, Andayani \& Diah, 2013). Pengetahuan tentang menstruasi dapat diperoleh dari berbagai sumber informasi seperti keluarga, kelompok teman sebaya, lingkungan sekolah, dan media baik cetak maupun elektronik. Sumber informasi utama sebenarnya berasal dari ibu dan kakak perempuan.

Penelitian Budiati dan Apriastuti (2012), mengungkapkan banyak remaja yang memiliki informasi yang salah dan cenderung mengkaitkan menstruasi dengan sesuatu yang negatif. Kondisi tersebut pada akhirnya menyebabkan anak menjadi tidak siap untuk menerima menarche dan mengalami kesulitan dalam menghadapinya.

Berdasarkan data penelitian diketahui kelekatan aman anak dan ibu pada remaja putri prapubertas di SD Budi Mulia Dua Seturan berada pada kategori sangat tinggi. Dimana semua subjek dengan jumlah 74 siswi memiliki kategorisasi sangat tinggi dengan persentase $100 \%$. Hasil tersebut menunjukkan bahwa semua remaja putri 
prapubertas di SD Budi Mulia Dua Seturan yang menjadi subjek penelitian merasakan kelekatan aman antara dirinya dan ibu yang sangat baik.

\section{Simpulan dan Saran}

Terdapat hubungan positif yang signifikan antara kelekatan aman anak dan ibu dengan kesiapan menghadapi menstruasi pertama (menarche) pada remaja putri prapubertas. Semakin tinggi kelekatan aman anak dan ibu maka semakin tinggi pula kesiapan menghadapi menstruasi pertama (menarche) pada remaja. Sebaliknya, semakin rendah kelekatan aman anak dan ibu maka semakin rendah pula kesiapan menghadapi menstruasi pertama (menarche) pada remaja.

Remaja putri prapubertas di SD Budi Mulia Dua memiliki kategorisasi kesiapan menghadapi menarche yang berada pada kategori tinggi yaitu sebesar $78.37 \%$ dengan jumlah sebanyak 58 siswi, sedangkan kategorisasi kelekatan aman berada pada kategori tinggi yaitu sebesar $100 \%$ dengan jumlah sebanyak 74 siswi.

Sumbangan efektif kelekatan aman terhadap kesiapan menghadapi menstruasi pertama (menarche) remaja putri prapubertas SD Budi Mulia Dua Seturan sebesar $9.3 \%$ yang dapat dilihat dari nilai $\mathrm{R}$ square $9.3 \%$ sedangkan $90.7 \%$ dipengaruhi oleh faktor-faktor lain seperti: usia, sumber informasi berupa teman sebaya dan lingkungan sekolah, dan sikap yang tidak diungkapkan dalam penelitian ini.

Berdasarkan hasil penelitian ini, peneliti menyarankan kepada para pihak yang terkait dengan remaja prapubertas yang sedang menghadapi menarche, terutama keluarga, dalam hal ini figur ibu, untuk menciptakan kelekatan aman dengan anak perempuannya agar mereka lebih siap dalam menghadapi menarche. Salah satu yang dapat dilakukan adalah dengan menjalin komunikasi dan interaksi yang terbuka, serta menyediakan informasi yang dibutuhkan terkait menarche. Selain itu, bagi peneliti selanjutnya yang tertarik meneliti topik yang sama, dapat meneliti dan menganalisa variabel-variabel lain yang secara teoritis berhubungan dengan kesiapan menghadapi menarche, diantaranya seperti faktor usia, sumber informasi berupa kelompok teman sebaya dan lingkungan sekolah, dan sikap.

\section{Daftar Pustaka}

Astiti, F. N., \& Pudjono, M. (2004). Hubungan antara pengetahuan sistem reproduksi dengan kecemasan menghadapi menarche. (Skripsi tidak diterbitkan). Universitas Islam Yogyakarta, Indonesia.

Baron, R. A., \& Byrne, D. (2003). Psikologi sosial (ed. 10). Jakarta: Erlangga.

Bharatwaj, R. S., Vijaya, K., \& Sindu, T. (2014). Psychosocial impact related to physiological changes preceding, at and following menarche among adolescent girls. International Journal of Clinical Surgical Advances, 2(1), 42-53.

Budiati, S., \& Apriastuti, D. A. (2012) Hubungan tingkat pengetahuan ibu tentang kesehatan reproduksi remaja dengan kesiapan anak menghadapi masa pubertas. Jurnal Kebidanan Estu Utomo Boyolali, 4(1).

Desmita (2005). Psikologi perkembangan. Bandung: Remaja Rosdakarya.

Dianawati, A. (2006). Pendidikan seks untuk remaja. Depok: PT Kawan Pustaka.

Fajri, A., \& Khairani, M. (2011). Hubungan antara komunikasi ibu-anak dengan kesiapan menghadapi menstruasi pertama (menarche) pada siswi Smp Muhammadiyah Banda Aceh. Jurnal Psikologi Undip, 10(2).

Helmi, A. F. (1999). Gaya kelekatan dan konsep diri. Jurnal Psikologi, 1(1), 917.

Hurlock, E. B. (2004). Psikologi perkembangan: Suatu pendekatan 
sepanjang rentang kehidupan (ed. 5). Jakarta: Erlangga.

Kartono, K. (2006). Psikologi wanita: Mengenal gadis remaja dan wanita dewasa. Bandung: Mandiri Maju.

McCartney, K. \& Dearing, E., (Ed). (2002). Child development. Woodbridge, CT, US: MacMillan Reference USA.

Muriyana, S. D. (2008). Studi kualitatif tentang kesiapan remaja putri sekolah dasar dalam menghadapi menarche pada usia 10-12 tahun (Skripsi tidak diterbitkan). Universitas Muhammadiyah Semarang.

Nastiti, F. D., Andayani, A., \& Diah, M. (2013). Hubungan tingkat pengetahuan menarche dengan kesiapan siswi kelas $v$ dan vi menghadapi menarche di SD Negeri 1 Gedanganak. Yogyakarta: Akademi Kebidanan Ngudi Waluyo.

Purnamasari, S. (2010). Hubungan pengetahuan kesehatan reproduksi dengan kesiapan menghadapi perubahan masa pubertas pada siswi kelas $v$ dan vi di SD Negeri 01 Candi Rejo Ungaran (Skripsi tidak diterbitkan). Stikes Ngudi Waluyo Ungaran.

Priherdityo, E. (23 Juli, 2016). Pernikahan usia anak masih marak di Indonesia. CNN Indonesia. Diakses pada 30 Agustus 2017 dari https://www.cnnindonesia.com/gayahidup/20160723074431-277-

146515/pernikahan-usia-anak-masihmarak-di-indonesia

Santrock, J. W. (2002). Life-span development: Perkembangan masa hidup (ed. 5). Jakarta: Erlangga.

Santrock, J. W. (2003). Adolescence: Perkembangan remaja. Jakarta: Erlangga.

Sarwono, S. W. (2010). Psikologi remaja. Jakarta: PT. Raja Grafindo Persada.

Sriwindari, D. (2002). Hubungan antara pengetahuan tentang menstruasi dengan kecemasan menghadapi menarche pada remaja putri prapubertas. Jurnal Psikodinamik, 4(2).

Suseno, M. N. (2012). Statistika: Teori dan aplikasi untuk penelitian ilmu sosial dan humaniora. Yogyakarta: AshShaff.

Tiwari, H., Oza. U. N., \& Tiwari, R. (2006). Knowledge, attitudes, and beliefs about menarche of adolescent girl in Anand District, Gujarat. La Revue de Sante de la Mediterranee Orientale, 12(3).

Yeung, Y. L., Tang, C. S., \& Lee, A. (2005). Psychososial and cultural factors influencing expectations of menarche: Study on Chinese premenarcheal teenage girls. Journal of Adolesescent Research, 20(1).

Yusuf, A. M. (2002). Pengantar ilmu pendidikan. Jakarta: Ghalia Indonesia

Yusuf, Y., Rina K., \& Septi, R. (2014). Hubungan pengetahuan menarche dengan kesiapan remaja putri menghadapi menarche di SMP Negeri 3 Tidore Kepulauan. Jurnal Keperawatan, 2(2). 